\title{
Frozen ground temperature trends associated with climate change in the Tibetan Plateau Three River Source Region from 1980 to 2014
}

\author{
Siqiong Luo ${ }^{1, *}$, Xuewei Fang ${ }^{1,2}$, Shihua Lyu ${ }^{1,3}$, Di Ma ${ }^{1}$, Yan Chang ${ }^{1}$, Minghong Song ${ }^{1}$, \\ Hao Chen ${ }^{1}$ \\ ${ }^{1}$ Key Laboratory of Land Surface Process and Climate Change in Cold and Arid Regions, \\ Cold and Arid Regions Environmental and Engineering Research Institute, Chinese Academy of Sciences, Lanzhou 730000, PR China \\ ${ }^{2}$ University of the Chinese Academy of Sciences, Beijing 100049, PR China \\ ${ }^{3}$ Chengdu University of Information Technology, Chengdu 610225, PR China
}

\begin{abstract}
Long-term (1981-2014) trends in soil temperatures at depths ranging from 0-320 cm were used to examine relationships between regional climate change and soil temperatures in the Three River Source Region (TRSR) of the Tibetan Plateau (TP). Air temperature, precipitation, maximum depth of frozen ground and maximum snow depth were also analysed for trends and for correlations with soil temperatures. A significant warming trend was evident in the TRSR during the $35 \mathrm{yr}$ analysed. Significant soil warming was detected, at rates of $0.706^{\circ} \mathrm{C}_{\text {decade }}{ }^{-1}$ for surface soils $(0 \mathrm{~cm}), 0.477^{\circ} \mathrm{C}$ decade $^{-1}$ for shallow layer soils $(5-20 \mathrm{~cm})$ and $0.417^{\circ} \mathrm{C}$ decade $^{-1}$ for deep layer soils $(40-320 \mathrm{~cm})$. There was a clear effect of air temperature on soil temperature, as seen from the concurrent significant increases in air and soil temperature trends and the strong correlation between them. The relationship between precipitation and soil temperatures was complicated. Higher levels of precipitation on the ground also resulted in higher soil temperatures during the summer in the frozen soil, while the process of freezing and thawing had an inhibitory effect on the soil temperature increase. The warming trends in soil temperature are expected to continue with the degradation of frozen soil in the TRSR.
\end{abstract}

KEY WORDS: Soil temperature trends · Frozen ground - Air temperature - Three River Source Region · Tibetan Plateau

\section{INTRODUCTION}

The important modulating role played by frozen ground on the land surface is strongly affected by climate. Observations and simulations have indicated that the frozen ground conditions of the earth are currently experiencing rapid changes in response to global warming associated with climate changeparticularly in the Tibetan Plateau (TP), a region that encompasses extensive areas of permafrost and seasonal frozen ground. Due to its unique geographical location and high altitude, the frozen ground on the TP differs from that of other high latitude regions.

${ }^{*}$ Corresponding author: lsq@lzb.ac.cn
The frozen ground of TP is relatively warm and thin compared with high latitude frozen ground in both North America and Russia, and thus is more sensitive to climate changes and surface conditions (Cheng 1998). Therefore, more reliable evidence and rapid changes can be anticipated in these regions in response to climate change (Cheng \& Jin 2013). Meteorological observatories have demonstrated that the TP has experienced statistically significant warming since the mid-1950s, especially during the winter (Liu \& Chen 2000). Areas of permafrost and seasonally frozen ground have decreased (Lawrence et al. 2012, Ran et al. 2012, Cheng \& Jin 2013, Guo \&

(C) The authors 2016. Open Access under Creative Commons by Attribution Licence. Use, distribution and reproduction are unrestricted. Authors and original publication must be credited. 
Wang 2013), the active layer has become much thicker, and the landscape over the TP has changed (Xue et al. 2009, Wu et al. 2012). From model simulations in the Coupled Model Intercomparison Project Phase 5 (CMIP5), the TP appears more sensitive and susceptible to climate change than other Chinese areas in future emission scenarios (You et al. 2014). A climate model has also demonstrated that air temperatures will rise, leading to a reduction in ice and frost over the TP in the next $35 \mathrm{yr}$ (Zhu et al. 2013). This deterioration of frozen ground may influence the energy and hydrological cycles of the TP, ultimately leading to further climate change (Chen et al. 2014).

A noteworthy feature of the TP frozen ground is that its temperature has continually risen over the past several decades. Based on monitoring data from 27 sites collected from 2006-2010, the mean rate of temperature increase of the permafrost at a depth of $6.0 \mathrm{~m}$ was $0.2^{\circ} \mathrm{C}$ decade $^{-1}$ (Wu et al. 2012). According to remote sensing data, surface soil temperatures have increased at an average rate of $0.6^{\circ} \mathrm{C}$ decade $^{-1}$ (Xue et al. 2009), and from borehole investigations, the temperature of the supra permafrost water has increased by $0.5-0.7^{\circ} \mathrm{C}$ between 1980 and 2005 in the Yellow River source region (Jin et al. 2009). Increases in soil temperature as a result of a warmer climate will have profound effects on surface and subsurface hydrologic conditions, thawing permafrost in high latitudes and at high altitudes, accelerating the decomposition of organic carbon in the soil, increasing the release of $\mathrm{CO}_{2}$ from the soil to the atmosphere and altering terrestrial ecosystems, thereby creating a positive feedback loop leading to further climate change (Nelson 2003, Davidson \& Janssens 2006, Kurylyk et al. 2014). Therefore, analysing the variability and trends in long-term soil temperatures at various depths may contribute to our understanding of the consequences of a warmer climate on surface energy processes and regional environmental and climatic conditions (Hu \& Feng 2003, Qian et al. 2011, Alamusa et al. 2014, Bai et al. 2014, Yeşilırmak 2014).

The Three River Source Region (TRSR), located in the northeastern TP, is an area in which China's 2 longest rivers (the Yangtze and Yellow) and a transnational river (the Mekong River; called Lancang in China) originate. This region has been given the name 'Chinese water tower', and is a mosaic transition zone of seasonal frozen ground and areas of discontinuous and continuous permafrost. In recent years, the trends in many climate parameters, including temperature, rainfall, evaporation, relative humidity and wind speed have been studied in the
TRSR because this region is particularly sensitive to the impacts of climate change (You et al. 2008, 2014, 2015, Yi et al. 2011, Guo \& Wang 2012, Xu et al. 2012, Liang et al. 2013). Meteorological data has demonstrated that air temperatures in the TRSR have been rising at an average rate of $0.32^{\circ} \mathrm{C}$ decade ${ }^{-1}$ for the past half century (Yi et al. 2011, Liang et al. 2013). The annual number of warm days and nights increased from 1961-2005 (You et al. 2008), and these warming trends have caused an increase in the number of permafrost thawing days and a thickening of the permafrost active layer (Xue et al. 2009). Data from boreholes indicates that the lower limit of the permafrost has risen by $50-80 \mathrm{~m}$, and that the average maximum depth of frost penetration has decreased by $0.1-0.2 \mathrm{~m}$ in the Yellow River source region since 1980 (Jin et al. 2009). Some permafrost has already disappeared, which has resulted in the disappearance of, or a lowering of the level of groundwater in the seasonal thawing layer. According to data collected at the Maduo weather station, seasonal frozen ground depths have decreased by $0.2 \mathrm{~m}$ since the 1980s (Jin et al. 2009).

Taken together, the research mentioned above has enhanced our understanding of the local frozen ground response to climate change in the TRSR. However, there are limitations to these studies, in that they focus only on local effects and use shortterm datasets. In order to achieve a more complete understanding, it is necessary to examine temporal and spatial changes in frozen ground relative to present conditions in the TRSR. In this paper, we analysed trends in the seasonal and annual means of soil temperatures from 1980-2014, using data collected at 9 meteorological stations across the TRSR at depths of $0,5,10,20,40,80,160$ and $320 \mathrm{~cm}$, and examined their relationships to air temperature, precipitation, maximum depth of frozen ground and maximum snow depth.

\section{STUDY REGION AND DATA}

The TRSR, located in the interior of the TP, China, contains the headwaters of the Yellow, Yangtze and Mekong Rivers (Fig. 1). It covers an area of $3.258 \times$ $10^{5} \mathrm{~km}^{2}$ with an average elevation of $4483 \mathrm{~m}$ above mean sea level (AMSL; range: 3217-6575 m AMSL). It is located in the sub-frigid zone of the TP, with annual air temperatures ranging between 4.2 and $-5.4^{\circ} \mathrm{C}$ (Zheng et al. 2010, Xu et al. 2012). Climate regionalization within the TP is characterized by humid, sub-humid and semi-arid zones (Zheng et al. 


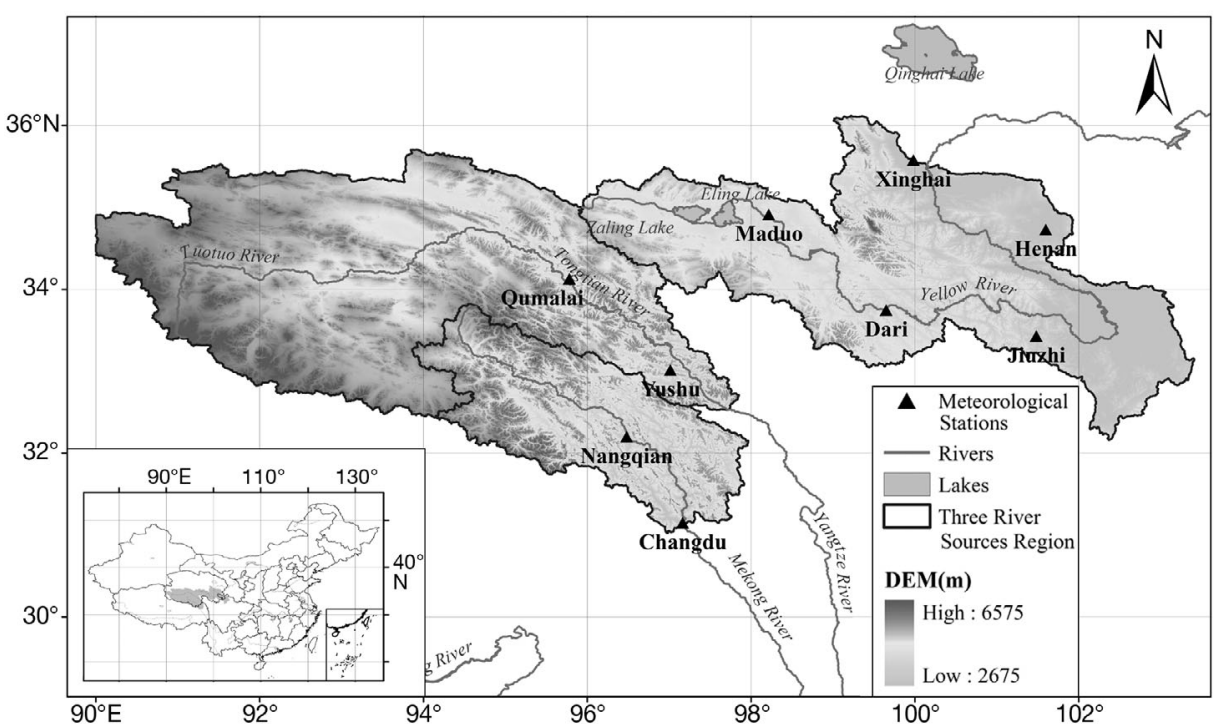

Fig. 1. Study area and locations of the meteorological stations $(\mathbf{\Lambda})$ used to collect climate data from 1980-2014 in the Three River Source Region (TRSR) of the Tibetan Plateau, China (inset)
2010). Precipitation varies, with annual accumulations ranging from $649 \mathrm{~mm}$ in the eastern part of the region (Ruoergai meteorological station) to $299 \mathrm{~mm}$ in the western precipitation occurs during the rainy season (May-September).

The data analysed in this study included surface $(0 \mathrm{~cm})$, shallow layer (depths of 5, 10, 15 and $20 \mathrm{~cm}$ ) and deep layer (depths of 40, 80, 160 and $320 \mathrm{~cm}$ ) soil temperatures collected from 9 meteorological stations operated by the China Meteorological Data Sharing Service System. In addition, data on air temperature, precipitation, maximum depth of frozen ground and maximum depth of snow were also included in this study. Soil temperature monitoring was conducted each day by trained professional meteorological technicians at all stations. The temperatures at depths of 0 , $5,10,15,20$ and $40 \mathrm{~cm}$ were measured 4 times $\mathrm{d}^{-1}$ (02:00, 08:00, 14:00, and 20:00 h Beijing Time) and av- eraged as a daily mean; temperatures at depths of 80, 160 and $320 \mathrm{~cm}$ were measured once $\mathrm{d}^{-1}$ (14:00 h Beijing Time) (CMA 2003). Surface and shallow layer soil temperatures were measured in bare soil with no overlying vegetation, whereas deep layer soil temperatures were measured in natural vegetation (CMA 2003). The depth of the frozen ground was observed once $\mathrm{d}^{-1}$ (08:00 $\mathrm{h}$ Beijing Time) by frozen soil apparatus when ground surface temperature was below $0^{\circ} \mathrm{C}$ (CMA 2003). All data were collected monthly at each station for $35 \mathrm{yr}$ (from 1980-2014); the monthly data were then used to create seasonal and annual time series. Seasons were defined as follows: spring = March, April and May; summer = June, July and August; autumn = September, October and November; and winter $=$ December, January and February. A list of the stations and their associated information is provided in Table 1; their locations are shown on Fig. 1.

Table 1. Details of the meteorological stations used to collect climate data from 1980-2014; height: m above mean sea level; ST: soil temperature

\begin{tabular}{|c|c|c|c|c|c|c|c|}
\hline Station name & $\begin{array}{l}\text { Station } \\
\text { number }\end{array}$ & $\begin{array}{l}\text { Latitude } \\
\left({ }^{\circ} \mathrm{N}\right)\end{array}$ & $\begin{array}{l}\text { Longitude } \\
\left({ }^{\circ} \mathrm{E}\right)\end{array}$ & $\begin{array}{l}\text { Height } \\
\text { (m) }\end{array}$ & $\begin{array}{l}\text { Data period for } \\
0 \mathrm{~cm} \mathrm{ST}\end{array}$ & $\begin{array}{l}\text { Data period for } \\
\text { shallow ST }\end{array}$ & $\begin{array}{c}\text { Data period for } \\
\text { deep ST }\end{array}$ \\
\hline \multicolumn{8}{|l|}{ Yellow River } \\
\hline Xinghai & 52943 & $35^{\circ} 35^{\prime}$ & $99^{\circ} 59^{\prime}$ & 3323 & 1980-2014 & 1980-2014 & none \\
\hline Henan & 56065 & $34^{\circ} 44^{\prime}$ & $101^{\circ} 36^{\prime}$ & 3500 & 1980-2014 & $1980-2014$ & $1981-2014$ \\
\hline Jiuzhi & 56067 & $33^{\circ} 26^{\prime}$ & $101^{\circ} 29^{\prime}$ & 3629 & $1980-2014$ & 1980-2014 & $1980-2014$ \\
\hline Dari & 56046 & $33^{\circ} 45^{\prime}$ & $99^{\circ} 39^{\prime}$ & 3968 & $1980-2014$ & 1980-2014 & $1980-2014$ \\
\hline Maduo & 56033 & $34^{\circ} 55^{\prime}$ & $98^{\circ} 13^{\prime}$ & 4272 & 1980-2014 & 1980-2014 & 1980-2014 \\
\hline \multicolumn{8}{|l|}{ Yangtze River } \\
\hline Qumalai & 56021 & $34^{\circ} 08^{\prime}$ & $95^{\circ} 47^{\prime}$ & 4175 & 1980-2014 & 1980-2014 & $1982-2014$ \\
\hline Yushu & 56029 & $33^{\circ} 01^{\prime}$ & $97^{\circ} 01^{\prime}$ & 3681 & $1980-2014$ & $1980-2014$ & none \\
\hline \multicolumn{8}{|l|}{ Mekong River } \\
\hline Nangqian & 56125 & $32^{\circ} 12^{\prime}$ & $96^{\circ} 29^{\prime}$ & 3644 & 1980-2014 & 1980-2014 & none \\
\hline Changdu & 56137 & $31^{\circ} 09^{\prime}$ & $97^{\circ} 10^{\prime}$ & 3306 & $1980-2014$ & $1980-2014$ & 1980-2014 \\
\hline
\end{tabular}




\section{METHODS}

For this study, 2 non-parametric methods, the modified Mann-Kendall trend (MMK) test (Mann 1945, Kendall 1955, Hamed \& Rao 1998) and Sen's slope estimator (Sen 1968), were used in Matlab (MathWorks) to detect trends in soil temperatures and other meteorological variables. These methods used have been widely used to quantify the significance of trends in hydro-meteorological time series (Gocic \& Trajkovic 2013). Correlation analysis was used to identify relationships between soil temperature variability and other climate variables at the same locations, which is a commonly used method of statistical diagnosis in modern climatic analysis studies (Wei 2007).

\subsection{Modified Mann-Kendall trend test}

The MMK (Mann 1945, Kendall 1955, Hamed \& Rao 1998) test statistic ( $S$ ) was calculated as:

$$
S=\sum_{i=1}^{n-1} \sum_{j=i+1}^{n} \operatorname{sgn}\left(x_{j}-x_{i}\right)
$$

where $n$ is the number of data points, $x_{i}$ and $x_{j}$ are the data values in time series $i$ and $j(j>i)$, respectively and $\operatorname{sgn}\left(x_{j}-x_{i}\right)$ is:

$$
\operatorname{sgn}\left(x_{j}-x_{i}\right)=\left\{\begin{array}{l}
+1, \text { if } x_{j}-x_{i}>0 \\
0, \text { if } x_{j}-x_{i}=0 \\
-1, \text { if } x_{j}-x_{i}<0
\end{array}\right.
$$

The variance was computed as:

$$
\operatorname{Var}(S)=\frac{n(n-1)(2 n+5)-\sum_{i=1}^{m} t_{i}\left(t_{i}-1\right)\left(2 t_{i}+5\right)}{18}
$$

where $n$ is the number of data points, $m$ is the number of tied groups and $t_{i}$ denotes the number of ties of extent $i$. A tied group is a set of sample data having the same value. The null hypothesis in the MannKendall test is that the data are independent and randomly ordered. However, the existence of positive autocorrelation in the data increases the probability of detecting trends when none actually exist, and vice versa (Hamed \& Rao 1998). In order to remove the effects of autocorrelation for the data, we amended the modified variance, $\operatorname{Var}^{*}(S)$, as follows:

$$
\beta=\operatorname{median} \frac{x_{j}-x_{i}}{j-i} \quad(1 \leq i<j \leq n)
$$

where $\beta$ is the trend estimator based on the sequence rank. The stable sequence corresponding with the original, which eliminated the trend $\left\{y_{i}\right\}_{i=1}^{n}$, is represented as:

$$
r(i)=\frac{\sum_{k=1}^{n-i}\left(R_{k}-R\right)\left(R_{k+i}-R\right)}{\sum_{k=1}^{n}\left(R_{k}-R\right)^{2}}
$$

where $r(i)$ is the autocorrelation function of the ranks of the observations, $R_{i}$ is the rank of $y_{i}$ and $R$ is the mean rank order of $y_{i}$. Using:

$$
\eta=1+\frac{2}{n(n-1)(n-2)} \times \sum_{i=1}^{n-1}(n-i)(n-i-1)(n-i-2) r(i)
$$

where $\eta$ represents a correction due to the autocorrelation in the data, we can calculate:

$$
\operatorname{Var}^{*}(S)=\eta \times \operatorname{Var}(S)
$$

In cases where the sample size $n>10$, the standard normal test statistic, $Z$, is computed using Eq. (4):

$$
Z= \begin{cases}\frac{S-1}{\sqrt{\operatorname{Var}^{*}(S)},}, & \text { if } S>0 \\ 0, & \text { if } S=0 \\ \frac{S+1}{\sqrt{\operatorname{Var}^{*}(S)},}, & \text { if } S<0\end{cases}
$$

Positive values of $Z$ indicate increasing trends while negative values show decreasing trends.

Testing trends is done at a specific significance level. When $|Z|>Z_{1-\alpha / 2}$, the null hypothesis is rejected and a significant trend exists in the time series. $Z_{1-\alpha / 2}$ is obtained from the standard normal distribution table. In this study, significance levels of $\alpha=0.01$ and 0.05 were used. At the $5 \%$ significance level, the null hypothesis of no trend was rejected if $|Z|>1.96$, and at the $1 \%$ significance level if $|Z|>2.576$.

\subsection{Sen's slope estimator}

Sen (Sen 1968) developed the following non-parametric procedure for estimating the slope of the trend $\left(Q_{\mathrm{i}}\right)$ in a sample of $N$ pairs of data:

$$
Q_{i}=\frac{x_{j}-x_{k}}{j-k} \text { for } i=1, \ldots, N,
$$

where $x_{j}$ and $x_{k}$ are data values at times $j$ and $k(j>k)$, respectively.

If there is only one datum in each time period, then $N=\frac{n(n-1)}{2}$, where $n$ is the number of time periods. If there are multiple observations in one or more time periods, then $N<\frac{n(n-1)}{2}$, where $n$ is the total number of observations. 
The $N$ values of $Q_{i}$ are ranked from smallest to largest and the median of the slope, or Sen's slope estimator $\left(Q_{\mathrm{med}}\right)$, is computed as:

$$
Q_{\text {med }}= \begin{cases}Q_{[(N+1) / 2] r}, & \text { if } N \text { is odd } \\ \frac{Q_{[N / 2]}+Q_{[(N+2) / 2]}}{2}, & \text { if } N \text { is even }\end{cases}
$$

The $Q_{\text {med }}$ sign reflects data trend, while its value indicates the steepness of the trend. To determine whether the median slope is statistically different than zero, the confidence interval of $Q_{\text {med }}$ at specific probability can be obtained. The confidence interval about the time slope (Gilbert 1987, Hollander et al. 1999) is computed as follows:

$$
C_{\mathrm{a}}=Z_{1-\alpha / 2} \sqrt{\operatorname{Var}^{*}(S)}
$$

where $\operatorname{Var}^{*}(S)$ is defined in Eq. (8), and $Z_{1-\alpha / 2}$ is obtained from the standard normal distribution table. In this study, the confidence interval was computed at 2 significance levels ( $\alpha=0.01$ and 0.05$)$.
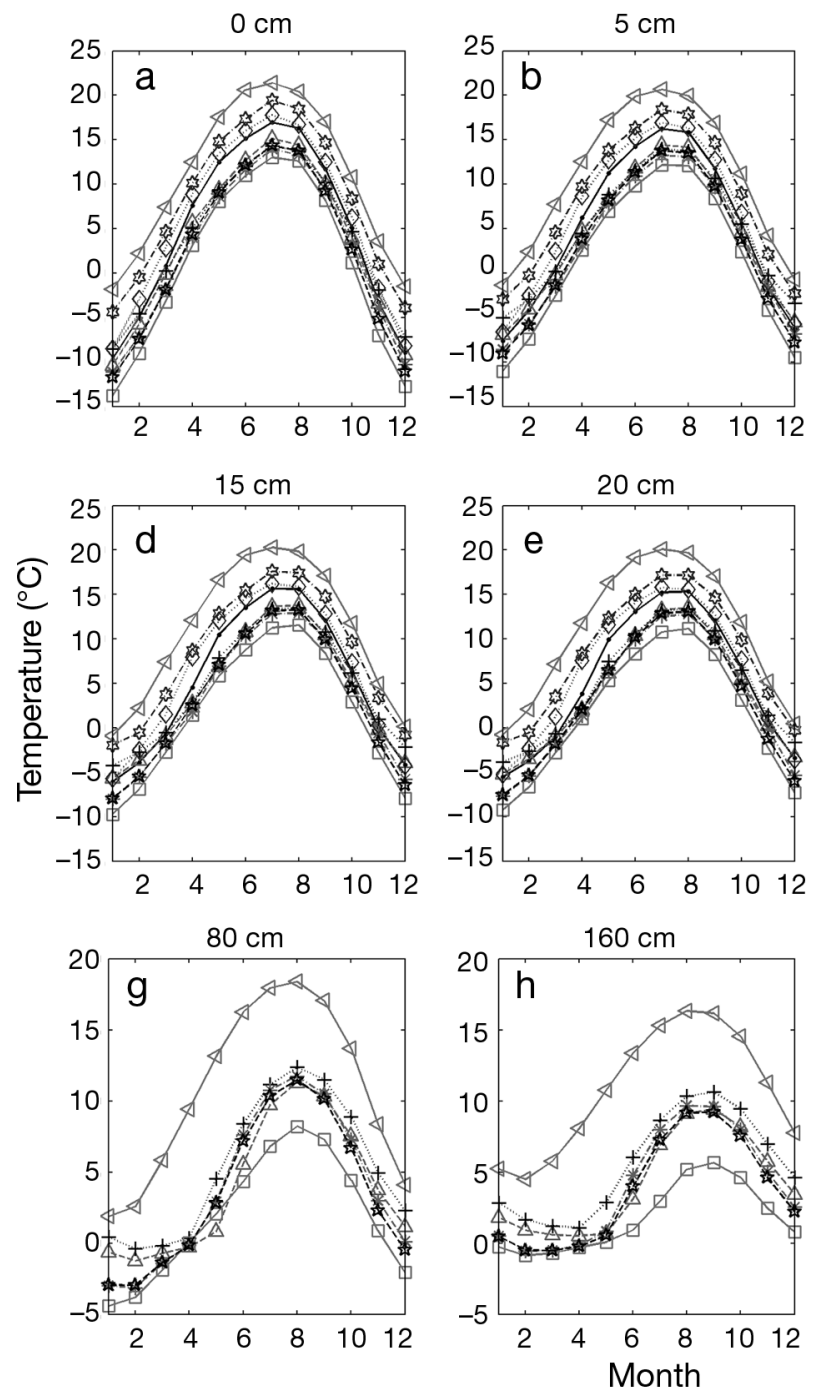

Then, $M_{1}=\frac{N-C_{\alpha}}{2}$ and $M_{2}=\frac{N+C_{\alpha}}{2}$ are computed. The lower and upper limits of the confidence interval, $Q_{\min }$ and $Q_{\max }$ are the $M_{1}^{\text {th }}$ largest and the $\left(M_{2}+1\right)^{\text {th }}$ largest of the $N$ ordered slope estimates (Gilbert 1987).

The slope of $Q_{\text {med }}$ is statistically different than zero if the 2 limits $\left(Q_{\min }\right.$ and $\left.Q_{\max }\right)$ have similar sign.

\section{SOIL TEMPERATURE CLIMATOLOGY}

Changes in seasonal soil temperature cycles from 0-320 cm depth recorded at the 9 meteorological stations between 1980 and 2012 are shown in Fig. 2. The annual mean soil temperature during that period was $4.693^{\circ} \mathrm{C}$. Regarding spatial distribution throughout the study region, the Maduo station recorded the lowest soil temperature $\left(1.629^{\circ} \mathrm{C}\right)$, while the Changdu station had the highest $\left(10.832^{\circ} \mathrm{C}\right)$. Soil temperatures are usually affected by solar radiation, air tem-
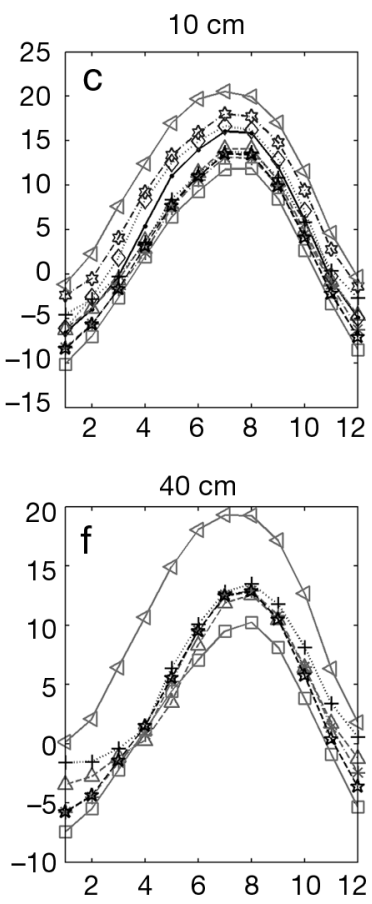

Fig. 2. Monthly mean soil temperature cycles across 35 yr (see Table 1 for data periods) from $0-320 \mathrm{~cm}$ depth at the Three River Source Region (TRSR) meteorological stations (see Fig. 1)

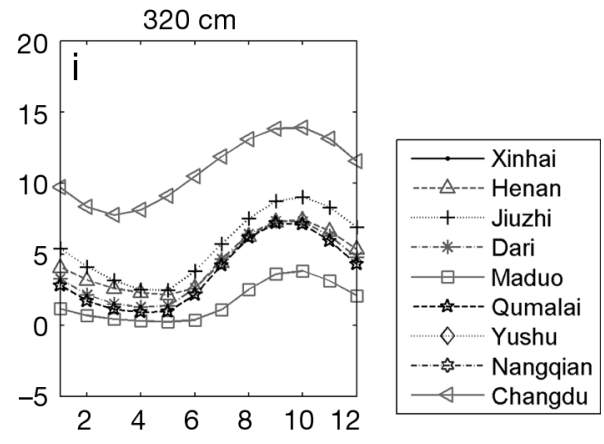


Table 2. Trends in seasonal and annual mean soil temperatures $\left({ }^{\circ} \mathrm{C}\right.$ decade ${ }^{-1}$ ) across 35 yr (see Table 1 for data periods) at the 9 Three River Source Region (TRSR) meteorological stations (Fig. 1) for 3 different layers (surface, shallow and deep). $Z$ : modified Mann-Kendall test statistic; slope: Sen's slope estimator; significance levels: ${ }^{*} \alpha=0.05,{ }^{* *} \alpha=0.01$

\begin{tabular}{|c|c|c|c|c|c|c|c|c|c|c|}
\hline & \multicolumn{2}{|c|}{- Spring -} & \multicolumn{2}{|c|}{- Summer } & \multicolumn{2}{|c|}{-Autumn — } & \multicolumn{2}{|c|}{ - Winter -} & \multicolumn{2}{|c|}{ - Annual } \\
\hline & $Z$ & Slope & $Z$ & Slope & $Z$ & Slope & $Z$ & Slope & $Z$ & Slope \\
\hline \multicolumn{11}{|c|}{ Surface $(0 \mathrm{~cm})$} \\
\hline Xinghai & $4.460^{* *}$ & $0.606^{* *}$ & $2.798^{* *}$ & $0.500^{* *}$ & $4.162^{* *}$ & $0.667^{* *}$ & $3.198^{* *}$ & $0.571^{* *}$ & $5.568^{* *}$ & $0.583^{* *}$ \\
\hline Henan & $4.460^{* *}$ & $0.988^{* *}$ & $5.015^{* *}$ & $0.950^{* *}$ & $4.447^{* *}$ & $0.754^{* *}$ & $4.276^{* *}$ & $0.912^{* *}$ & $5.340^{* *}$ & $0.946^{* *}$ \\
\hline Jiuzhi & $4.192^{* *}$ & $0.773^{* *}$ & $4.533^{* *}$ & $0.636^{* *}$ & $4.035^{* *}$ & $0.583^{* *}$ & $4.716^{* *}$ & $1.161^{* *}$ & $5.368^{* *}$ & $0.768^{* *}$ \\
\hline Dari & $3.324^{* *}$ & $0.507^{* *}$ & $2.330^{*}$ & $0.321^{*}$ & $2.884^{* *}$ & $0.410^{* *}$ & $2.969^{* *}$ & $0.652^{* *}$ & $3.891^{* *}$ & $0.492^{* *}$ \\
\hline Maduo & $3.963^{* *}$ & $0.756^{* *}$ & $3.908^{* *}$ & $0.584^{* *}$ & $4.035^{* *}$ & $0.667^{* *}$ & $3.765^{* *}$ & $0.778^{* *}$ & $4.773^{* *}$ & $0.688^{* *}$ \\
\hline Qumalai & $4.235^{* *}$ & $0.650^{* *}$ & $3.410^{* *}$ & $0.500^{* *}$ & $4.275^{* *}$ & $0.800^{* *}$ & $5.541^{* *}$ & $1.222^{* *}$ & $5.624^{* *}$ & $0.820^{* *}$ \\
\hline Yushu & $3.352^{* *}$ & $0.500^{* *}$ & $2.785^{* *}$ & $0.476^{* *}$ & $5.085^{* *}$ & $0.624^{* *}$ & $4.503^{* *}$ & $1.455^{* *}$ & $5.724^{* *}$ & $0.768^{* *}$ \\
\hline Nangqian & $3.750^{* *}$ & $0.758^{* *}$ & $3.623^{* *}$ & $0.689^{* *}$ & $4.221^{* *}$ & $0.604^{* *}$ & $5.285^{* *}$ & $0.939^{* *}$ & $4.830^{* *}$ & $0.722^{* *}$ \\
\hline Changdu & $3.838^{* *}$ & $0.521^{* *}$ & 1.492 & 0.391 & $2.787^{* *}$ & $0.424^{* *}$ & $4.517^{* *}$ & $0.902^{* *}$ & $4.290^{* *}$ & $0.569^{* *}$ \\
\hline Average & $3.908^{* *}$ & $0.669^{* *}$ & $3.282^{* *}$ & $0.561^{* *}$ & $3.965^{* *}$ & $0.615^{* *}$ & $4.255^{* *}$ & $0.955^{* *}$ & $5.011^{* *}$ & $0.706^{* *}$ \\
\hline \multicolumn{11}{|c|}{ Shallow (average of $5,10,15,20 \mathrm{~cm}$ ) } \\
\hline Xinghai & $2.970^{* *}$ & $0.414^{* *}$ & $2.694^{* *}$ & $0.403^{* *}$ & $3.768^{* *}$ & $0.383^{* *}$ & $3.419^{* *}$ & $0.361^{* *}$ & $4.740^{* *}$ & $0.394^{* *}$ \\
\hline Henan & $4.115^{* *}$ & $0.615^{* *}$ & $4.801^{* *}$ & $0.721^{* *}$ & $4.029^{* *}$ & $0.442^{* *}$ & $2.886^{* *}$ & $0.326^{* *}$ & $5.177^{* *}$ & $0.553^{* *}$ \\
\hline Jiuzhi & $4.949^{* *}$ & $0.632^{* *}$ & $5.321^{* *}$ & $0.651^{* *}$ & $4.420^{* *}$ & $0.499^{* *}$ & $4.514^{* *}$ & $0.450^{* *}$ & $5.931^{* *}$ & $0.542^{* *}$ \\
\hline Dari & $3.657^{* *}$ & $0.408^{* *}$ & $3.827^{* *}$ & $0.441^{* *}$ & $2.581^{* *}$ & $0.246^{* *}$ & $3.369^{* *}$ & $0.389^{* *}$ & $4.457^{* *}$ & $0.364^{* *}$ \\
\hline Maduo & $4.171^{* *}$ & $0.525^{* *}$ & $4.851^{* *}$ & $0.710^{* *}$ & $3.830^{* *}$ & $0.449^{* *}$ & 1.776 & 0.306 & $5.423^{* *}$ & $0.495^{* *}$ \\
\hline Qumalai & $4.950^{* *}$ & $0.610^{* *}$ & $4.760^{* *}$ & $0.612^{* *}$ & $3.681^{* *}$ & $0.401^{* *}$ & $4.101^{* *}$ & $0.557^{* *}$ & $5.876^{* *}$ & $0.578^{* *}$ \\
\hline Yushu & 0.910 & 0.119 & $3.745^{* *}$ & $0.459^{* *}$ & $4.404^{* *}$ & $0.469^{* *}$ & $4.753^{* *}$ & $0.927^{* *}$ & $5.486^{* *}$ & $0.495^{* *}$ \\
\hline Nangqian & $3.716^{* *}$ & $0.476^{* *}$ & $3.954^{* *}$ & $0.592^{* *}$ & $3.206^{* *}$ & $0.391^{* *}$ & $5.323^{* *}$ & $0.393^{* *}$ & $4.865^{* *}$ & $0.453^{* *}$ \\
\hline Changdu & $3.600^{* *}$ & $0.370^{* *}$ & 1.659 & 0.342 & $2.150^{*}$ & $0.332^{*}$ & $4.355^{* *}$ & $0.675^{* *}$ & $3.661^{* *}$ & $0.423^{* *}$ \\
\hline Average & $3.671^{* *}$ & $0.463^{* *}$ & $3.957^{* *}$ & $0.548^{* *}$ & $3.563^{* *}$ & $0.401^{* *}$ & $3.833^{* *}$ & $0.487^{* *}$ & $5.068^{* *}$ & $0.477^{* *}$ \\
\hline \multicolumn{11}{|c|}{ Deep (average of $40,80,160,320 \mathrm{~cm}$ ) } \\
\hline Henan & $4.809^{* *}$ & $0.321^{* *}$ & $4.932^{* *}$ & $0.793^{* *}$ & $4.846^{* *}$ & $0.461^{* *}$ & $4.425^{* *}$ & $0.277^{* *}$ & $5.446^{* *}$ & $0.469^{* *}$ \\
\hline Jiuzhi & $4.453^{* *}$ & $0.424^{* *}$ & $5.720^{* *}$ & $0.746^{* *}$ & $3.473^{* *}$ & $0.314^{* *}$ & 1.146 & 0.077 & $5.238^{* *}$ & $0.395^{* *}$ \\
\hline Dari & $3.647^{* *}$ & $0.310^{* *}$ & $4.677^{* *}$ & $0.514^{* *}$ & $3.747^{* *}$ & $0.312^{* *}$ & $3.866^{* *}$ & $0.257^{* *}$ & $4.880^{* *}$ & $0.346^{* *}$ \\
\hline Maduo & $6.243^{* *}$ & $0.477^{* *}$ & $6.031^{* *}$ & $1.243^{* *}$ & $5.483^{* *}$ & $0.638^{* *}$ & 0.261 & -0.137 & $6.431^{* *}$ & $0.549^{* *}$ \\
\hline Qumalai & $3.563^{* *}$ & $0.294^{* *}$ & $4.628^{* *}$ & $0.593^{* *}$ & $2.929^{* *}$ & $0.248^{* *}$ & 1.302 & 0.110 & $4.038^{* *}$ & $0.320^{* *}$ \\
\hline Changdu & $2.305^{*}$ & $0.364^{*}$ & 1.898 & 0.444 & $2.824^{* *}$ & $0.465^{* *}$ & $3.944^{* *}$ & $0.471^{* *}$ & $2.706^{* *}$ & $0.422^{* *}$ \\
\hline Average & $4.170^{* *}$ & $0.365^{* *}$ & $4.647^{* *}$ & $0.722^{* *}$ & $3.883^{* *}$ & $0.406^{* *}$ & $2.491^{*}$ & $0.176^{*}$ & $4.790^{* *}$ & $0.417^{* *}$ \\
\hline
\end{tabular}

perature and terrain variables. Maduo is a northerly station, located at the maximum height AMSL of all the stations, while Changdu is an extreme southern station, at the minimum height (Table 1).

For surface $(0 \mathrm{~cm})$ and $5 \mathrm{~cm}$ soils, the minimum recorded temperature occurred in January and the maximum in July at all stations. Below the surface, the minimum and maximum temperatures occurred later than their corresponding values at the surface, with time lag increasing with depth. The minimum soil temperatures occurred in January, and the maximum in July or August at depths of 10, 15, 20 and $40 \mathrm{~cm}$. The minimum temperature at $80 \mathrm{~cm}$ depth was recorded in January (Maduo and Changdu) or February (Henan, Jiuzhi, Dari and Qumalai), and the maximum in August. The minimum temperature at $160 \mathrm{~cm}$ occurred in February (Dari, Maduo and Changdu), March (Qumalai) or April (Henan and Jiuzhi), while the maximum occurred in August (Dari and Changdu) or September (Henan, Jiuzhi, Maduo and Qumalai). The minimum temperature at $320 \mathrm{~cm}$ occurred in March (Changdu), April (Dari and Qumalai) or May (Henan, Jiuzhi and Maduo), and the maximum occurred in September (Dari and Qumalai) or October (Henan, Jiuzhi, Maduo and Changdu). The maximum seasonal amplitude of soil temperature $\left(25.161^{\circ} \mathrm{C}\right)$ occurred at $0 \mathrm{~cm}$, from $22.822^{\circ} \mathrm{C}$ (Jiuzhi) to $26.852^{\circ} \mathrm{C}$ (Maduo); this value decreased with increasing depth. The soil temperature seasonal amplitudes for the 4 shallow layers $(5-20 \mathrm{~cm})$ averaged 22.094, 21.278, 20.561 and $19.903^{\circ} \mathrm{C}$, respectively, which were higher than that of the 4 deep layers $(40-320 \mathrm{~cm})$, at $17.548,13.955$, 9.456 and $5.633^{\circ} \mathrm{C}$, respectively.

\section{SOIL TEMPERATURE TRENDS}

Trends in annual, seasonal and monthly mean soil temperatures at the 9 TRSR stations collected during 


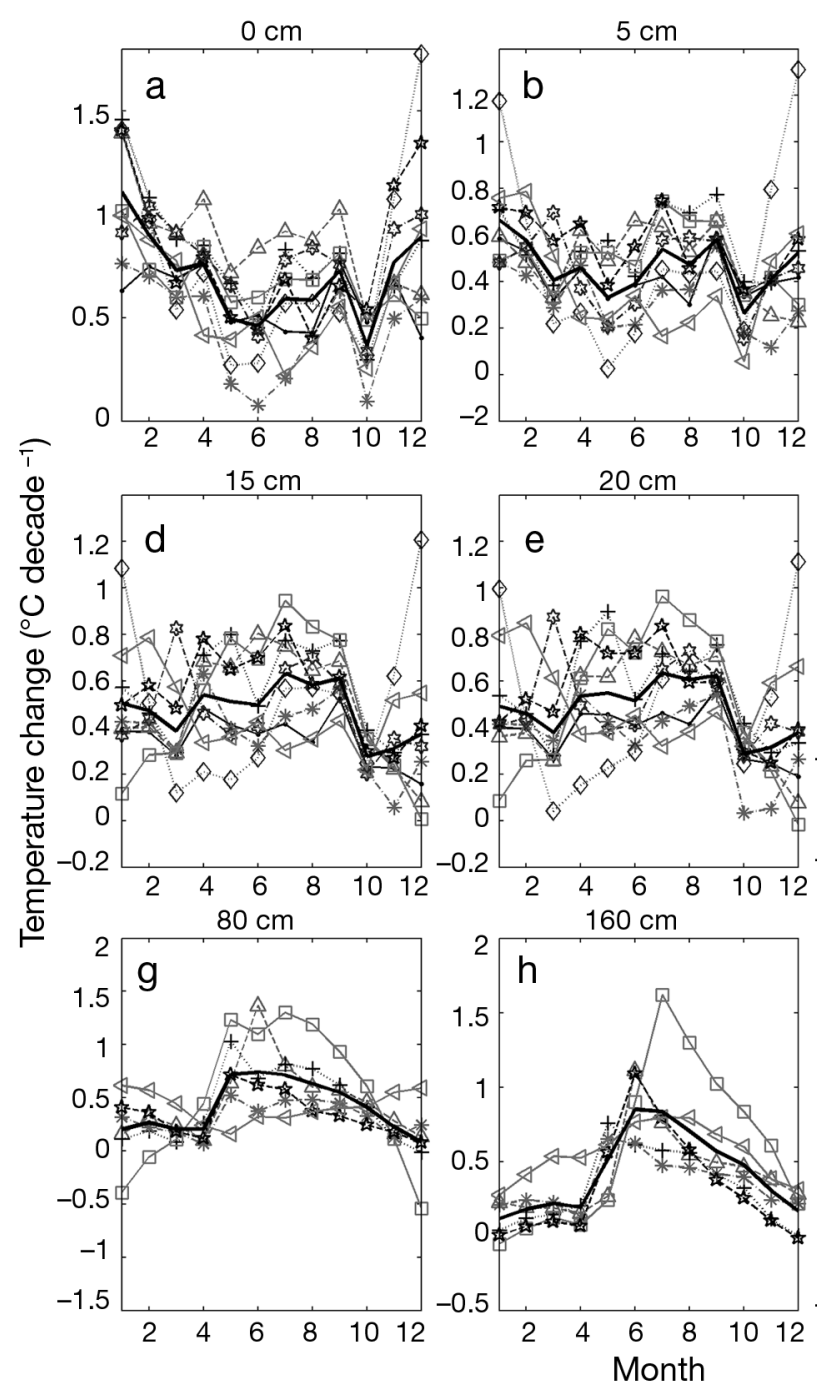

1980-2014 are shown in Table 2 and Fig. 3. The spatial distributions of each layer with increasing, decreasing or no trends for the seasonal and annual data series are also presented in Figs. S1 \& S2 in the Supplement at www.int-res.com/articles/suppl/ c067p241_supp.pdf.

\subsection{Surface soil temperature trends}

Seasonal and annual mean surface soil temperatures for the entire TRSR increased significantly between 1980 and 2014 (Table 2). On an annual time scale, increasing trends were detected at a $1 \%$ significance level at all stations, with an average rate of $0.706^{\circ} \mathrm{C}$ decade $^{-1}$, varying between $0.946^{\circ} \mathrm{C}$ decade $^{-1}$ at Henan station and $0.492^{\circ} \mathrm{C} \mathrm{decade}^{-1}$ at Dari station.

Regarding monthly distributions (Fig. 3a), larger warming trends of surface soil temperatures were
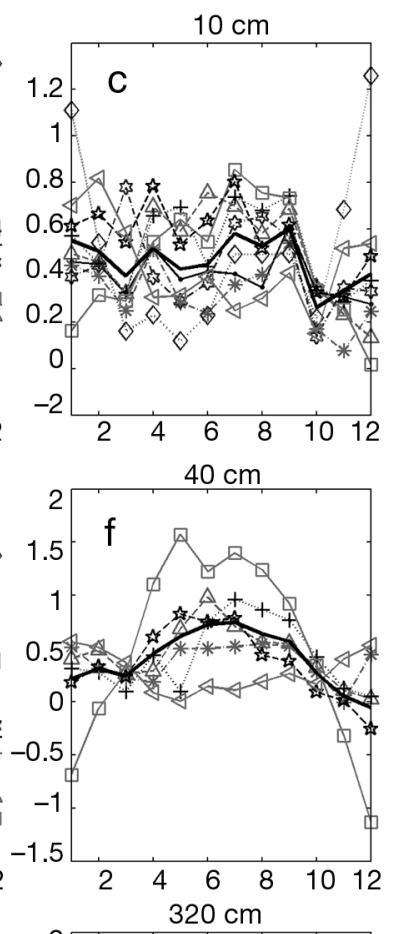

Fig. 3. Trends in monthly mean soil temperature across 35 yr (see Table 1 for data periods) from 0-320 $\mathrm{cm}$ depth at the Three River Source Region (TRSR) meteorological stations

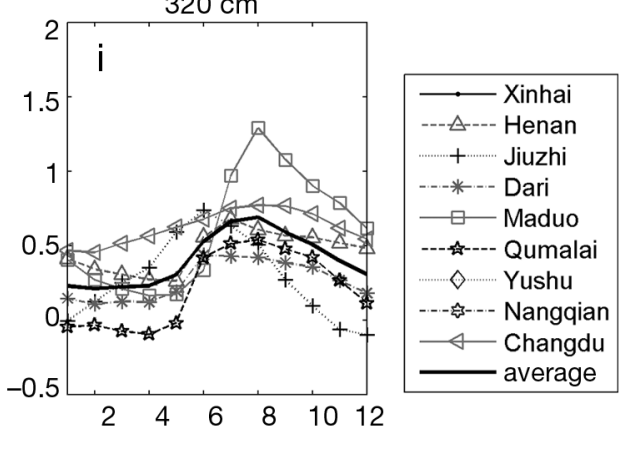

observed in January, November and December, while smaller trends occurred in June and October. These trends also exhibited significant seasonal variation. As shown in Table 2, the maximum warming trends occurred in winter for 7 stations, with the exception of Xinghai and Henan. The average trend in winter exhibited an increase of $0.955^{\circ} \mathrm{C}$ decade $^{-1}$, which was more than $70 \%$ that of the summer rate $\left(0.561^{\circ} \mathrm{C}\right.$ decade $\left.^{-1}\right)$. The values in spring and autumn were $0.669^{\circ} \mathrm{C}$ decade $^{-1}$ and $0.615^{\circ} \mathrm{C}$ decade $^{-1}$, respectively. These results indicate that the rate of increase in surface soil temperatures is greater in winter than during the other seasons.

\subsection{Shallow soil temperature trends}

Annual mean soil temperatures in the 4 shallow layers warmed significantly (at $\alpha=0.01$ ) at all 9 stations across the TRSR over the $35 \mathrm{yr}$ analysed, with 
an average rate increase of $0.477^{\circ} \mathrm{C}$ decade $^{-1}$ (Table 2). In terms of vertical distribution (Fig. S1), there was no significant increase or decrease in warming trend with soil depth. Regarding spatial distribution across the TRSR, the trends of the shallow layers were similar to that at the surface, with greater warming occurring at Henan $\left(0.553^{\circ} \mathrm{C}\right.$ decade $\left.^{-1}\right)$ and Qumalai stations $\left(0.578^{\circ} \mathrm{C}\right.$ decade $\left.^{-1}\right)$, respectively, and a less of a warming trend seen at Dari station $\left(0.364^{\circ} \mathrm{C}\right.$ decade $\left.^{-1}\right)$.

The monthly trends in shallow soil temperatures differed considerably across the TRSR (Fig. 3b-e). The greatest warming trends in the 4 shallow depths were recorded in July, August and September at most stations. Significant warming trends were also found in January and December in stations such as Henan and Changdu - a similar pattern to that observed in surface soil temperatures. There was a common characteristic, in that the warming trends were relatively small in October at all depths and all stations. One of the major reasons for this occurrence is that the freezing process is a buffer to seasonal changes in soil temperatures (discussed in more detail in Section 6.2). On a seasonal scale, the percentage of stations characterized by significant increasing trends (at $\alpha=0.05$ ) in shallow layer soil temperatures was $88.89 \%$ for spring, $94.44 \%$ for summer, $97.22 \%$ for autumn and $91.67 \%$ for winter. As shown in Fig. S1, the strongest warming trends occurred in winter for 5 stations at $5 \mathrm{~cm}$ soil layers, while the strongest warming trends occurred in summer at 10, 15 and $20 \mathrm{~cm}$ soil layers for most stations $(5,6$ and 6 stations, respectively). As shown in Table 2, the largest warming trends in all shallow layers occurred in the summer at 6 stations (Henan, Jiuzhi, Dari, Maduo, Qumalai and Nangqian), in winter at 2 stations (Yushu and Changdu), and in spring at 1 station (Xinghai). This also suggest that the increasing rate in summer $\left(0.548^{\circ} \mathrm{C}\right.$ decade $\left.^{-1}\right)$ is greater than that of other seasons $\left(0.463^{\circ} \mathrm{C}\right.$ decade ${ }^{-1}$, $0.401^{\circ} \mathrm{C}$ decade $^{-1}$ and $0.487^{\circ} \mathrm{C}$ decade $^{-1}$, in spring, autumn and winter, respectively) for all shallow layer soils.

\subsection{Deep soil temperature trends}

The soil temperatures of the 4 deep layers increased significantly (at $\alpha=0.01$ ) at 6 stations across the TRSR over $35 \mathrm{yr}$, with an average increasing rate of $0.417^{\circ} \mathrm{C}$ decade $^{-1}$. Warming that occurs in the upper layers could take some time to reach the deeper layers. Other recent studies have produced similar results (Qian et al. 2011). With respect to spatial distribution, the greatest warming trend for the deep layer soils occurred at the Maduo station $\left(0.549^{\circ} \mathrm{C}\right.$ decade $\left.{ }^{-1}\right)$, while the lowest trend occurred at the Qumalai station $\left(0.320^{\circ} \mathrm{C}\right.$ decade $\left.^{-1}\right)$.

The trends in temperatures of the deep layer soils also exhibited significant seasonal variation. Significant soil warming occurred from April or May until September or October at depths of 40 and $80 \mathrm{~cm}$ for 5 of the 6 stations (except Changdu; Fig. 3f,g). Significant soil warming from May or June until October or November was found at depths of 160 and $320 \mathrm{~cm}$ at all stations (Fig. 3h,i). The strongest warming trends in summer (average rate: $0.722^{\circ} \mathrm{C}$ decade $^{-1}$ ) was nearly 4 times that in winter $\left(0.176^{\circ} \mathrm{C}\right.$ decade $\left.^{-1}\right)$ in the TRSR. Soil temperature warming trends in spring and autumn were $0.365^{\circ} \mathrm{C}$ decade $^{-1}$ and $0.406^{\circ} \mathrm{C}$ decade $^{-1}$, respectively. The percentage of stations characterized by significant at $(\alpha=0.05)$ increasing trends was $91.67 \%$ for spring, summer and autumn, and $62.50 \%$ for winter. As shown in Fig. S2, there were only 2 significant changes in decreasing direction (at $\alpha=0.05$ ): during winter at Maduo station at 40 and $80 \mathrm{~cm}$ depths, at rates of -0.667 and $-0.353^{\circ} \mathrm{C}$ decade $^{-1}$, respectively. The strongest trends occurred in the summer for 5 stations at the 40 and $80 \mathrm{~cm}$ depths, (again except for Changdu), for which the strongest trend occurred in winter. For the 160 and $320 \mathrm{~cm}$ soil layers, the strongest trends were also observed in summer at all 6 stations, except for the $320 \mathrm{~cm}$ soil layer at Maduo station, for which the strongest warming occurred in autumn. This implies that increases in the summer contributed more to increases in the winter for all deep layer soil in the TRSR.

\section{DISCUSSION}

\subsection{Trends in other climate variables}

Annual means and trends in air temperature, total precipitation, maximum depth of frozen ground and maximum snow depth are provided in Table 3 and in Figs. 4 \& Fig. S3 in the Supplement at www.int-res. com/articles/suppl/c067p241_supp.pdf. As shown in Table 3, over the last $35 \mathrm{yr}$ the mean annual air temperature in the TRSR was $1.502^{\circ} \mathrm{C}$. Half of the meteorological stations measured air temperatures below $0^{\circ} \mathrm{C}$. Maduo station recorded the lowest air temperature at $-3.250^{\circ} \mathrm{C}$, while Changdu station had the highest air temperature at $7.834^{\circ} \mathrm{C}$, which was similar to the soil temperatures in the study region. All 
Table 3. Annual means in air temperature, total precipitation, maximum depth of frozen ground and maximum depth of snow recorded at the Three River Source Region (TRSR) meteorological stations across 35 yr (see Table 1)

\begin{tabular}{|lcccc|}
\hline & $\begin{array}{c}\text { Air } \\
\text { temperature } \\
\left({ }^{\circ} \mathrm{C}\right)\end{array}$ & $\begin{array}{c}\text { Total } \\
\text { precipitation } \\
(\mathrm{mm})\end{array}$ & $\begin{array}{c}\text { Max. frozen } \\
\text { depth } \\
(\mathrm{cm})\end{array}$ & $\begin{array}{c}\text { Max. snow } \\
\text { depth } \\
(\mathrm{cm})\end{array}$ \\
\hline Xinghai & 1.726 & 374.457 & 156.971 & 4.629 \\
Henan & -0.137 & 564.526 & 122.114 & 8.800 \\
Jiuzhi & 1.112 & 737.423 & 90.114 & 11.400 \\
Dari & -0.454 & 565.937 & 196.559 & 9.943 \\
Maduo & -3.250 & 335.383 & 213.059 & 7.229 \\
Qumalai & -1.660 & 430.266 & 202.121 & 7.171 \\
Yushu & 3.706 & 492.849 & 89.706 & 6.857 \\
Nangqian & 4.637 & 549.251 & 66.029 & 6.229 \\
Changdu & 7.834 & 487.286 & 48.429 & 4.514 \\
Average & 1.502 & 504.156 & 131.678 & 7.419 \\
\hline
\end{tabular}

cade $\left.^{-1}\right)$, were larger than in autumn $\left(0.380^{\circ} \mathrm{C}\right.$ decade $\left.^{-1}\right)$ and spring $\left(0.366^{\circ} \mathrm{C}\right.$ decade $^{-1}$ ). The greater rate of soil temperature warming in winter was likely caused by the vegetation growing over the TP in summer, which would attenuate surface warming (Shen et al. 2015). As described in Section 5, surface and $5 \mathrm{~cm}$ depth soil warming occurred mainly during the winter, with soil temperature increases in the summer more evident in the other layers $(10-320 \mathrm{~cm})$ at most stations. These results indicate that only surface soil temperatures are consistent with air temperatures. The mean annual increasing trends for surface soil temperatures $(0 \mathrm{~cm})$ were greater than those for air temperature at all stations. For all shallow layer soils, the mean annual increasing trends were greater than those for air temperature at 5 stations (Xinghai, Henan, Jiuzhi, Yushu and Changdu). For all deep layer soils, 2 stations (Maduo and Changdu) showed mean annual increasing trends for soil temperature that were greater than those for air temperature. Similar results (i.e. increasing trends in soil temperature being stronger than that for air temperature) have been found elsewhere in the TP and in Russia (Zhang et al. 2001, GarcíaSuárez \& Butler 2006, Du et al. 2007).

As shown in Table 3, mean annual precipitation for the 9 stations across the TRSR measured $504.156 \mathrm{~mm}$, with the least amount $(335.383 \mathrm{~mm})$ recorded in Maduo and the highest $(737.423 \mathrm{~mm})$ in Jiuzhi. A positive trend in seasonal and annual precipitation was detected at about two-thirds of the stations (Fig. S3). There were 3 significant changes in increasing direction (at $\alpha=0.05$ ): spring in Yushu,

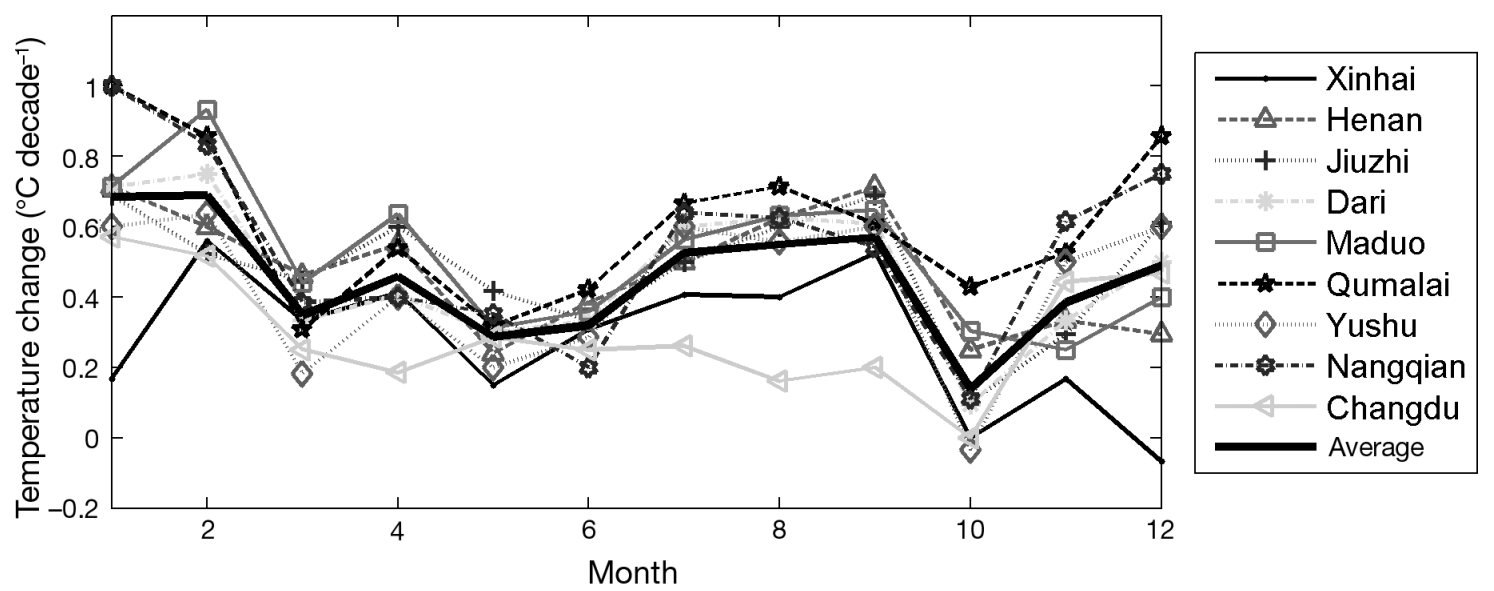

Fig. 4. Trends in monthly mean air temperature across 35 yr (see Table 1 for data periods) at the Three River Source Region (TRSR) meteorological stations (see Fig. 1) 
Table 4. Correlation coefficients for seasonal and annual air temperature and soil temperature across 35 yr (see Table 1) for the 9 TRSR stations (Fig. 1). Significance levels: ${ }^{*} \alpha=0.05_{;}{ }^{* *} \alpha=0.01$

\begin{tabular}{|c|c|c|c|c|c|c|c|c|c|}
\hline & $0 \mathrm{~cm}$ & $5 \mathrm{~cm}$ & $10 \mathrm{~cm}$ & $15 \mathrm{~cm}$ & $20 \mathrm{~cm}$ & $40 \mathrm{~cm}$ & $80 \mathrm{~cm}$ & $160 \mathrm{~cm}$ & $320 \mathrm{~cm}$ \\
\hline \multicolumn{10}{|l|}{ Spring } \\
\hline Xinghai & $0.562^{* *}$ & $0.662^{* *}$ & $0.684^{* *}$ & $0.676^{* *}$ & $0.652^{* *}$ & none & none & none & none \\
\hline Henan & $0.681^{* *}$ & $0.733^{* *}$ & $0.732^{* *}$ & $0.728^{* *}$ & $0.731^{* *}$ & $0.767^{* *}$ & $0.781^{* *}$ & $0.820^{* *}$ & $0.776^{* *}$ \\
\hline Jiuzhi & $0.727^{* *}$ & $0.719^{* *}$ & $0.690^{* *}$ & $0.698^{* *}$ & $0.676^{* *}$ & $0.625^{* *}$ & $0.611^{* *}$ & $0.562^{* *}$ & $0.630^{* *}$ \\
\hline Dari & $0.644^{* *}$ & $0.645^{* *}$ & $0.671^{* *}$ & $0.670^{* *}$ & $0.627^{* *}$ & $0.610^{* *}$ & $0.623^{* *}$ & $0.628^{* *}$ & $0.528^{* *}$ \\
\hline Maduo & $0.654^{* *}$ & $0.556^{* *}$ & $0.600^{* *}$ & $0.609^{* *}$ & $0.641^{* *}$ & $0.637^{* *}$ & $0.651^{* *}$ & $0.667^{* *}$ & $0.653^{* *}$ \\
\hline Qumalai & $0.585^{* *}$ & $0.588^{* *}$ & $0.599^{* *}$ & $0.590^{* *}$ & $0.584^{* *}$ & $0.607^{* *}$ & $0.656^{* *}$ & $0.652^{* *}$ & $0.526^{* *}$ \\
\hline Yushu & $0.505^{* *}$ & $0.610^{* *}$ & $0.601^{* *}$ & $0.602^{* *}$ & $0.574^{* *}$ & none & none & none & none \\
\hline Nangqian & $0.649^{* *}$ & $0.636^{* *}$ & $0.633^{* *}$ & $0.637^{* *}$ & $0.634^{* *}$ & none & none & none & none \\
\hline Changdu & $0.566^{* *}$ & $0.559^{* *}$ & $0.553^{* *}$ & $0.526^{* *}$ & $0.539^{* *}$ & $0.483^{* *}$ & $0.495^{* *}$ & $0.490^{* *}$ & $0.434^{* *}$ \\
\hline \multicolumn{10}{|l|}{ Summer } \\
\hline Xinghai & $0.676^{* *}$ & $0.742^{* *}$ & $0.713^{* *}$ & $0.722^{* *}$ & $0.714^{* *}$ & none & none & none & none \\
\hline Henan & $0.794^{* *}$ & $0.796^{* *}$ & $0.815^{* *}$ & $0.824^{* *}$ & $0.820^{* *}$ & $0.740^{* *}$ & $0.775^{* *}$ & $0.770^{* *}$ & $0.780^{* *}$ \\
\hline Jiuzhi & $0.697^{* *}$ & $0.828^{* *}$ & $0.829^{* *}$ & $0.810^{* *}$ & $0.784^{* *}$ & $0.838^{* *}$ & $0.855^{* *}$ & $0.856^{* *}$ & $0.828^{* *}$ \\
\hline Dari & $0.742^{* *}$ & $0.795^{* *}$ & $0.795^{* *}$ & $0.811^{* *}$ & $0.795^{* *}$ & $0.761^{* *}$ & $0.723^{* *}$ & $0.763^{* *}$ & $0.733^{* *}$ \\
\hline Maduo & $0.676^{* *}$ & $0.686^{* *}$ & $0.702^{* *}$ & $0.658^{* *}$ & $0.694^{* *}$ & $0.753^{* *}$ & $0.765^{* *}$ & $0.729^{* *}$ & $0.691^{* *}$ \\
\hline Qumalai & $0.748^{* *}$ & $0.771^{* *}$ & $0.742^{* *}$ & $0.763^{* *}$ & $0.737^{* *}$ & $0.683^{* *}$ & $0.727^{* *}$ & $0.723^{* *}$ & $0.576^{* *}$ \\
\hline Yushu & $0.653^{* *}$ & $0.604^{* *}$ & $0.622^{* *}$ & $0.626^{* *}$ & $0.617^{* *}$ & none & none & none & none \\
\hline Nangqian & $0.830^{* *}$ & $0.865^{* *}$ & $0.854^{* *}$ & $0.854^{* *}$ & $0.842^{* *}$ & none & none & none & none \\
\hline Changdu & $0.718^{* *}$ & $0.724^{* *}$ & $0.746^{* *}$ & $0.757^{* *}$ & $0.751^{* *}$ & $0.801^{* *}$ & $0.783^{* *}$ & $0.741^{* *}$ & $0.689^{* *}$ \\
\hline \multicolumn{10}{|l|}{ Autumn } \\
\hline Xinghai & $0.437^{* *}$ & $0.476^{* *}$ & $0.444^{* *}$ & $0.446^{* *}$ & $0.431^{* *}$ & none & none & none & none \\
\hline Henan & $0.565^{* *}$ & $0.587^{* *}$ & $0.600^{* *}$ & $0.583^{* *}$ & $0.587^{* *}$ & $0.444^{* *}$ & $0.524^{* *}$ & $0.488^{* *}$ & $0.541^{* *}$ \\
\hline Jiuzhi & $0.541^{* *}$ & $0.609^{* *}$ & $0.659^{* *}$ & $0.656^{* *}$ & $0.652^{* *}$ & $0.638^{* *}$ & $0.645^{* *}$ & $0.604^{* *}$ & $0.567^{* *}$ \\
\hline Dari & $0.567^{* *}$ & $0.677^{* *}$ & $0.652^{* *}$ & $0.657^{* *}$ & $0.678^{* *}$ & $0.630^{* *}$ & $0.576^{* *}$ & 0.554 & 0.421 \\
\hline Maduo & $0.523^{* *}$ & $0.543^{* *}$ & $0.528^{* *}$ & $0.531^{* *}$ & $0.507^{* *}$ & $0.527^{* *}$ & $0.479^{* *}$ & 0.416 & 0.439 \\
\hline Qumalai & $0.602^{* *}$ & $0.601^{* *}$ & $0.600^{* *}$ & $0.606^{* *}$ & $0.606^{* *}$ & $0.509^{* *}$ & $0.447^{* *}$ & $0.374^{*}$ & $0.388^{*}$ \\
\hline Yushu & $0.543^{* *}$ & $0.554^{* *}$ & $0.560^{* *}$ & $0.539^{* *}$ & $0.549^{* *}$ & none & none & none & none \\
\hline Nangqian & $0.654^{* *}$ & $0.664^{* *}$ & $0.647^{* *}$ & $0.654^{* *}$ & $0.637^{* *}$ & none & none & none & none \\
\hline Changdu & $0.685^{* *}$ & $0.691^{* *}$ & $0.705^{* *}$ & $0.703^{* *}$ & $0.685^{* *}$ & $0.652^{* *}$ & $0.623^{* *}$ & $0.551^{* *}$ & $0.446^{* *}$ \\
\hline \multicolumn{10}{|l|}{ Winter } \\
\hline Xinghai & $0.590^{* *}$ & $0.586^{* *}$ & $0.651^{* *}$ & $0.616^{* *}$ & $0.623^{* *}$ & none & none & none & none \\
\hline Henan & $0.748^{* *}$ & $0.732^{* *}$ & $0.739^{* *}$ & $0.746^{* *}$ & $0.751^{* *}$ & $0.650^{* *}$ & $0.714^{* *}$ & $0.704^{* *}$ & $0.674^{* *}$ \\
\hline Jiuzhi & $0.745^{* *}$ & $0.732^{* *}$ & $0.737^{* *}$ & $0.725^{* *}$ & $0.702^{* *}$ & $0.659^{* *}$ & $0.644^{* *}$ & $0.610^{* *}$ & $0.657^{* *}$ \\
\hline Dari & $0.818^{* *}$ & $0.813^{* *}$ & $0.792^{* *}$ & $0.775^{* *}$ & $0.760^{* *}$ & $0.646^{* *}$ & $0.674^{* *}$ & $0.627^{* *}$ & $0.573^{* *}$ \\
\hline Maduo & $0.755^{* *}$ & $0.728^{* *}$ & $0.743^{* *}$ & $0.702^{* *}$ & $0.673^{* *}$ & $0.722^{* *}$ & $0.686^{* *}$ & $0.641^{* *}$ & $0.607^{* *}$ \\
\hline Qumalai & $0.790^{* *}$ & $0.772^{* *}$ & $0.773^{* *}$ & $0.782^{* *}$ & $0.780^{* *}$ & $0.768^{* *}$ & $0.778^{* *}$ & $0.761^{* *}$ & $0.679^{* *}$ \\
\hline Yushu & $0.599^{* *}$ & $0.591^{* *}$ & $0.595^{* *}$ & $0.594^{* *}$ & $0.580^{* *}$ & none & none & none & none \\
\hline Nangqian & $0.784^{* *}$ & $0.758^{* *}$ & $0.769^{* *}$ & $0.780^{* *}$ & $0.769^{* *}$ & none & none & none & none \\
\hline Changdu & $0.617^{* *}$ & $0.652^{* *}$ & $0.628^{* *}$ & $0.615^{* *}$ & $0.610^{* *}$ & $0.467^{* *}$ & $0.519^{* *}$ & $0.544^{* *}$ & $0.564^{* *}$ \\
\hline \multicolumn{10}{|l|}{ Annual } \\
\hline Xinghai & $0.571^{* *}$ & $0.924^{* *}$ & $0.932^{* *}$ & $0.916^{* *}$ & $0.898^{* *}$ & none & none & none & none \\
\hline Henan & $0.894^{* *}$ & $0.909^{* *}$ & $0.921^{* *}$ & $0.921^{* *}$ & $0.924^{* *}$ & $0.823^{* *}$ & $0.897^{* *}$ & $0.889^{* *}$ & $0.880^{* *}$ \\
\hline Jiuzhi & $0.861^{* *}$ & $0.920^{* *}$ & $0.924^{* *}$ & $0.903^{* *}$ & $0.781^{* *}$ & $0.876^{* *}$ & $0.866^{* *}$ & $0.819^{* *}$ & $0.840^{* *}$ \\
\hline Dari & $0.889^{* *}$ & $0.669^{* *}$ & $0.926^{* *}$ & $0.923^{* *}$ & $0.914^{* *}$ & $0.826^{* *}$ & $0.451^{* *}$ & $0.791^{* *}$ & $0.693^{* *}$ \\
\hline Maduo & $0.885^{* *}$ & $0.843^{* *}$ & $0.870^{* *}$ & $0.835^{* *}$ & $0.825^{* *}$ & $0.880^{* *}$ & $0.854^{* *}$ & $0.780^{* *}$ & $0.781^{* *}$ \\
\hline Qumalai & $0.888^{* *}$ & $0.692^{* *}$ & $0.702^{* *}$ & $0.735^{* *}$ & $0.729^{* *}$ & $0.836^{* *}$ & $0.838^{* *}$ & $0.794^{* *}$ & $0.696^{* *}$ \\
\hline Yushu & $0.742^{* *}$ & $0.590^{* *}$ & $0.619^{* *}$ & $0.617^{* *}$ & $0.637^{* *}$ & none & none & none & none \\
\hline Nangqian & $0.918^{* *}$ & $0.913^{* *}$ & $0.914^{* *}$ & $0.923^{* *}$ & $0.908^{* *}$ & none & none & none & none \\
\hline Changdu & $0.907^{* *}$ & $0.921^{* *}$ & $0.922^{* *}$ & $0.913^{* *}$ & $0.906^{* *}$ & $0.820^{* *}$ & $0.832^{* *}$ & $0.803^{* *}$ & $0.739^{* *}$ \\
\hline
\end{tabular}

spring in Nangqian, and summer in Maduo, at rates of $10.773,11.412$ and $16.000 \mathrm{~mm}$ decade $^{-1}$, respectively.

The average maximum depth of frozen ground at the 9 stations was $131.678 \mathrm{~cm}$, with the lowest depth
$(48.429 \mathrm{~cm})$ at Changdu and the highest depth $(213.059 \mathrm{~cm})$ at Maduo (Table 3). This depth gradually decreased for all stations over time, with an average decreasing trend over $35 \mathrm{yr}$ of $10.161 \mathrm{~cm}$ decade $^{-1}$. Statistically significant trends (at $\alpha=0.01$ ) at 
Table 5. Correlation coefficients for seasonal and annual precipitation and soil temperature across 35 yr (see Table) for the 9 TRSR stations (Fig. 1). Significance levels: ${ }^{*} \alpha=0.05 ;{ }^{* *} \alpha=0.01$

\begin{tabular}{|c|c|c|c|c|c|c|c|c|c|}
\hline & $0 \mathrm{~cm}$ & $5 \mathrm{~cm}$ & $10 \mathrm{~cm}$ & $15 \mathrm{~cm}$ & $20 \mathrm{~cm}$ & $40 \mathrm{~cm}$ & $80 \mathrm{~cm}$ & $160 \mathrm{~cm}$ & $320 \mathrm{~cm}$ \\
\hline \multicolumn{10}{|l|}{ Spring } \\
\hline Xinghai & -0.170 & -0.267 & -0.166 & -0.217 & -0.194 & none & none & none & none \\
\hline Henan & -0.190 & -0.256 & -0.227 & -0.213 & -0.198 & -0.126 & -0.090 & -0.149 & -0.132 \\
\hline Jiuzhi & 0.041 & 0.140 & 0.135 & 0.143 & 0.125 & 0.222 & 0.246 & 0.275 & 0.260 \\
\hline Dari & 0.175 & 0.215 & 0.224 & 0.237 & 0.240 & 0.210 & 0.217 & 0.251 & 0.273 \\
\hline Maduo & $-0.339^{*}$ & -0.194 & -0.198 & -0.180 & -0.150 & -0.166 & -0.118 & -0.105 & -0.082 \\
\hline Qumalai & 0.243 & 0.222 & 0.210 & 0.238 & 0.234 & 0.193 & 0.161 & 0.168 & 0.186 \\
\hline Yushu & $0.452^{* *}$ & $0.353^{*}$ & $0.364^{*}$ & $0.363^{*}$ & $0.381^{*}$ & none & none & none & none \\
\hline Nangqian & 0.287 & 0.282 & 0.323 & $0.333^{*}$ & 0.308 & none & none & none & none \\
\hline Changdu & 0.096 & 0.045 & 0.082 & 0.074 & 0.084 & -0.009 & 0.044 & 0.071 & 0.116 \\
\hline \multicolumn{10}{|l|}{ Summer } \\
\hline Xinghai & 0.187 & 0.167 & 0.183 & 0.143 & 0.132 & none & none & none & none \\
\hline Henan & -0.065 & -0.237 & -0.210 & -0.194 & -0.178 & 0.024 & 0.026 & -0.069 & -0.060 \\
\hline Jiuzhi & 0.163 & 0.118 & 0.131 & 0.073 & 0.072 & 0.193 & 0.183 & 0.291 & 0.194 \\
\hline Dari & $0.374^{*}$ & 0.258 & 0.278 & 0.323 & 0.269 & 0.315 & $0.458^{* *}$ & $0.400^{*}$ & $0.411^{*}$ \\
\hline Maduo & $0.376^{*}$ & $0.442^{* *}$ & $0.416^{*}$ & $0.478^{* *}$ & $0.464^{* *}$ & $0.430^{*}$ & $0.479^{* *}$ & $0.447^{* *}$ & $0.441^{* *}$ \\
\hline Qumalai & 0.314 & 0.240 & 0.273 & 0.289 & 0.300 & $0.384^{*}$ & $0.347^{*}$ & 0.314 & 0.338 \\
\hline Yushu & -0.184 & -0.095 & -0.091 & -0.072 & -0.098 & none & none & none & none \\
\hline Nangqian & -0.044 & -0.113 & -0.166 & -0.159 & -0.162 & none & none & none & none \\
\hline Changdu & -0.166 & -0.227 & -0.216 & -0.216 & -0.187 & -0.238 & -0.188 & -0.134 & -0.114 \\
\hline \multicolumn{10}{|l|}{ Autumn } \\
\hline Xinghai & 0.146 & 0.236 & 0.232 & 0.157 & 0.145 & none & none & none & none \\
\hline Henan & 0.247 & 0.033 & 0.055 & 0.073 & 0.097 & -0.008 & 0.110 & 0.056 & 0.170 \\
\hline Jiuzhi & -0.113 & -0.180 & -0.106 & -0.157 & -0.116 & -0.010 & -0.006 & 0.092 & 0.026 \\
\hline Dari & -0.081 & 0.001 & -0.030 & -0.086 & -0.100 & -0.068 & -0.056 & -0.105 & -0.009 \\
\hline Maduo & 0.027 & -0.019 & 0.016 & 0.047 & 0.082 & 0.078 & 0.163 & 0.183 & 0.179 \\
\hline Qumalai & 0.190 & 0.107 & 0.086 & 0.123 & 0.094 & 0.193 & 0.171 & 0.166 & 0.199 \\
\hline Yushu & -0.179 & -0.087 & -0.093 & -0.062 & -0.068 & none & none & none & none \\
\hline Nangqian & 0.067 & 0.067 & 0.125 & 0.146 & 0.190 & none & none & none & none \\
\hline Changdu & -0.282 & -0.195 & -0.216 & -0.274 & -0.272 & $-0.383^{*}$ & $-0.349^{*}$ & -0.323 & -0.261 \\
\hline \multicolumn{10}{|l|}{ Winter } \\
\hline Xinghai & -0.072 & -0.128 & -0.185 & -0.083 & -0.080 & none & none & none & none \\
\hline Henan & -0.151 & -0.063 & -0.072 & -0.094 & -0.114 & -0.042 & -0.140 & -0.129 & -0.142 \\
\hline Jiuzhi & 0.040 & 0.142 & 0.154 & 0.168 & 0.130 & 0.146 & 0.172 & 0.232 & 0.187 \\
\hline Dari & 0.035 & 0.041 & 0.074 & 0.089 & 0.105 & 0.276 & 0.232 & 0.254 & 0.266 \\
\hline Maduo & -0.219 & -0.083 & -0.133 & -0.112 & -0.129 & -0.238 & -0.229 & -0.221 & -0.210 \\
\hline Qumalai & 0.146 & 0.104 & 0.113 & 0.135 & 0.138 & 0.202 & 0.140 & 0.121 & 0.086 \\
\hline Yushu & 0.016 & 0.001 & 0.010 & -0.036 & 0.051 & none & none & none & none \\
\hline Nangqian & -0.089 & 0.030 & 0.079 & 0.088 & 0.072 & none & none & none & none \\
\hline Changdu & -0.058 & -0.012 & -0.042 & -0.051 & -0.083 & 0.124 & 0.063 & 0.002 & -0.010 \\
\hline \multicolumn{10}{|l|}{ Annual } \\
\hline Xinghai & 0.128 & 0.115 & 0.160 & 0.083 & 0.079 & none & none & none & none \\
\hline Henan & 0.008 & -0.232 & -0.194 & -0.172 & -0.147 & -0.022 & 0.037 & -0.073 & -0.085 \\
\hline Jiuzhi & 0.070 & 0.054 & 0.092 & 0.038 & 0.046 & 0.201 & 0.207 & 0.331 & 0.232 \\
\hline Dari & $0.338^{*}$ & 0.297 & 0.305 & 0.322 & 0.273 & $0.334^{*}$ & $0.456^{* *}$ & $0.400^{*}$ & $0.464^{* *}$ \\
\hline Maduo & 0.163 & 0.252 & 0.243 & 0.309 & 0.323 & 0.281 & $0.371^{*}$ & $0.360^{*}$ & $0.363^{*}$ \\
\hline Qumalai & $0.385^{*}$ & 0.290 & 0.306 & $0.340^{*}$ & $0.338^{*}$ & $0.422^{*}$ & $0.374^{*}$ & $0.348^{*}$ & $0.380^{*}$ \\
\hline Yushu & -0.098 & -0.021 & -0.017 & 0.005 & -0.007 & none & none & none & none \\
\hline Nangqian & 0.062 & 0.001 & -0.014 & 0.005 & 0.011 & none & none & none & none \\
\hline Changdu & -0.218 & -0.241 & -0.233 & -0.259 & -0.234 & -0.333 & -0.270 & -0.214 & -0.163 \\
\hline
\end{tabular}

8 of the meteorological stations (except Maduo) were all negative.

Average maximum snow depth at the 9 stations measured $7.419 \mathrm{~cm}$, with the thinnest layer $(4.5 \mathrm{~cm})$ at Changdu and the deepest $(11.4 \mathrm{~cm})$ at Jiuzhi. The maximum depth of snow at 4 stations gradually decreased, but the trend was not obvious. There was only 1 location (Changdu) that showed a significant (at $\alpha=0.01$ ) decreasing trend, with a rate of $-1.200 \mathrm{~cm}$ decade ${ }^{-1}$. 
Table 6. Correlation coefficients for maximum depth of frozen ground and snow with soil temperature across 35 yr (see Table 1) for the 9 TRSR stations (Fig. 1). Significance levels: ${ }^{*} \alpha=0.05 ;{ }^{* *} \alpha=0.01$

\begin{tabular}{|c|c|c|c|c|c|c|c|c|c|}
\hline & $0 \mathrm{~cm}$ & $5 \mathrm{~cm}$ & $10 \mathrm{~cm}$ & $15 \mathrm{~cm}$ & $20 \mathrm{~cm}$ & $40 \mathrm{~cm}$ & $80 \mathrm{~cm}$ & $160 \mathrm{~cm}$ & $320 \mathrm{~cm}$ \\
\hline \multicolumn{10}{|c|}{ Max. depth of frozen ground } \\
\hline Xinghai & $-0.679^{* *}$ & $-0.722^{* *}$ & $-0.758^{* *}$ & $-0.783^{* *}$ & $-0.804^{* *}$ & none & none & none & none \\
\hline Henan & $-0.464^{* *}$ & $-0.528^{* *}$ & $-0.575^{* *}$ & $-0.617^{* *}$ & $-0.653^{* *}$ & $-0.727^{* *}$ & $-0.860^{* *}$ & $-0.896^{* *}$ & $-0.755^{* *}$ \\
\hline Jiuzhi & $-0.592^{* *}$ & $-0.649^{* *}$ & $-0.688^{* *}$ & $-0.722^{* *}$ & $-0.748^{* *}$ & $-0.817^{* *}$ & $-0.871^{* *}$ & $-0.867^{* *}$ & $-0.619^{* *}$ \\
\hline Dari & $-0.447^{* *}$ & $-0.502^{* *}$ & $-0.533^{* *}$ & $-0.560^{* *}$ & $-0.583^{* *}$ & $-0.659^{* *}$ & $-0.622^{* *}$ & $-0.807^{* *}$ & $-0.700^{* *}$ \\
\hline Maduo & -0.173 & -0.231 & -0.266 & -0.293 & -0.319 & $-0.388^{*}$ & $-0.555^{* *}$ & $-0.798^{* *}$ & $-0.789^{* *}$ \\
\hline Qumalai & -0.264 & -0.316 & $-0.348^{*}$ & $-0.373^{*}$ & $-0.400^{*}$ & $-0.537^{* *}$ & $-0.622^{* *}$ & $-0.674^{* *}$ & $-0.507^{* *}$ \\
\hline Yushu & $-0.636^{* *}$ & $-0.645^{* *}$ & $-0.655^{* *}$ & $-0.662^{* *}$ & $-0.670^{* *}$ & none & none & none & none \\
\hline Nangqian & $-0.824^{* *}$ & $-0.836^{* *}$ & $-0.845^{* *}$ & $-0.853^{* *}$ & $-0.858^{* *}$ & none & none & none & none \\
\hline Changdu & $-0.790^{* *}$ & $-0.797^{* *}$ & $-0.800^{* *}$ & $-0.801^{* *}$ & $-0.804^{* *}$ & $-0.799^{* *}$ & $-0.780^{* *}$ & $-0.664^{* *}$ & -0.286 \\
\hline \multicolumn{10}{|c|}{ Max. depth of snow } \\
\hline Xinghai & $-0.429^{*}$ & $-0.443^{* *}$ & $-0.404^{*}$ & $-0.356^{*}$ & $-0.352^{*}$ & none & none & none & none \\
\hline Henan & $-0.495^{* *}$ & $-0.439^{* *}$ & $-0.446^{* *}$ & $-0.468^{* *}$ & $-0.487^{* *}$ & $-0.453^{* *}$ & $-0.450^{* *}$ & $-0.420^{*}$ & $-0.394^{*}$ \\
\hline Jiuzhi & -0.084 & -0.047 & -0.122 & -0.146 & -0.144 & -0.100 & -0.089 & -0.020 & -0.064 \\
\hline Dari & -0.018 & 0.014 & 0.037 & 0.019 & -0.026 & -0.061 & 0.034 & 0.034 & 0.069 \\
\hline Maduo & -0.075 & -0.051 & -0.032 & -0.048 & -0.008 & -0.072 & -0.088 & -0.048 & -0.055 \\
\hline Qumalai & -0.059 & -0.050 & -0.069 & -0.064 & -0.075 & 0.000 & 0.035 & 0.052 & 0.088 \\
\hline Yushu & 0.232 & 0.149 & 0.175 & 0.177 & 0.227 & none & none & none & none \\
\hline Nangqian & -0.280 & -0.200 & -0.165 & -0.154 & -0.126 & none & none & none & none \\
\hline Changdu & -0.148 & -0.077 & -0.092 & -0.114 & -0.141 & -0.073 & -0.149 & -0.261 & -0.333 \\
\hline
\end{tabular}

\subsection{Comparing soil temperature to other climate characteristics}

Relationships between air temperature, precipitation, maximum depth of frozen ground and maximum depth of snow with soil temperature are given in Tables 4-6. As expected, the correlations between seasonal and annual soil and air temperatures were significant and positive (at $\alpha=0.01$ ) at all stations and at all depths (Table 4). This relationship was stronger in the summer and winter than in spring and autumn. There were no evident decreasing correlation coefficients of air temperature on soil temperatures from the upper to deeper layers.

We expect that soil temperature and some climatic variables are interrelated, but there are many factors that influence soil temperatures at a local or site-specific scale. As shown in Table 5, there was no significant correlation between soil temperature and seasonal or annual precipitation at most stations in the TRSR region. Except at Maduo station, snow cover typically disappears by summer in this area of the TP. As shown in Table 6, there was no obvious correlation between soil temperature and maximum depth of snow, except at Xinghai and Henan stations, where there were negative correlations between these 2 factors. Previous studies have shown that more precipitation or snow on the ground normally results in lower soil temperatures in spring, summer and autumn, but higher soil temperatures in winter due to the thermal insulation effect of snow cover (Qian et al. 2011, Ye ilırmak 2014). A similar situation occurred in spring at the Yushu station and in winter at Maduo station. In spring, significant increases in precipitation at Yushu station (Fig. S3a2) resulted in a reduced rate of soil temperature increase, with the average rise in shallow soil temperature of only $0.119^{\circ} \mathrm{C}$ decade $^{-1}$ (Table 2). During winter, the soil temperature increase was relatively small (even negative), with an average rate of $0.306^{\circ} \mathrm{C}$ decade ${ }^{-1}$ in the shallow layers and $-0.137^{\circ} \mathrm{C}$ decade ${ }^{-1}$ in the deep layers (Table 2) as a result of less winter snow cover at Maduo station (Fig. S3d2). Precipitation or soil moisture plays an important role in soil temperature trends. An increase in soil moisture causes an increase in evaporation rates, which results in energy being absorbed from the surrounding soil, creating a soil temperature decrease despite air temperature increases; an effect known as the soil moisture feedback mechanism (Zhang et al. 2001). A similar situation occurred in summer at Henan station. In terms of the means of the trend magnitudes, soil temperatures at all layers increased faster (Table 2, Fig. S3b1) than the air temperature in summer, possibly due to slightly decreasing precipitation. An opposite tendency was observed in summer at the Maduo station. Soil temperatures at 
all layers, especially in the deep layers, increased faster $\left(0.710^{\circ} \mathrm{C}\right.$ decade ${ }^{-1}$ for shallow and $1.243^{\circ} \mathrm{C}$ decade $^{-1}$ for deep layers) than the air temperature $\left(0.526^{\circ} \mathrm{C}\right.$ decade $\left.^{-1}\right)$ with significant increasing precipitation (16.000 $\mathrm{mm}$ decade ${ }^{-1}$ ) in summer. Significant positive correlations (at $\alpha=0.05$ ) between soil temperatures and summer precipitation were observed at the Maduo station (Table 5). As shown in Table 3, the maximum depth of frozen ground was more than $2 \mathrm{~m}$ deep, and it occurred in spring or summer at Maduo. An increase in precipitation or soil moisture resulted in an increase in thawing rate, which released energy to the surrounding soil because those temperatures were higher than that of the frozen soil, creating a soil temperature increase. This resulted in the significantly positive correlations observed in summer. These results indicate that more precipitation or soil moisture on the ground also results in higher soil temperatures in summer during soil freezing season. Recent studies have shown that summer precipitation in the eastern region of the TP has increased over the past 50 yr (Zhang et al. 2009, Hu \& Liang 2013). Increasing trends of frozen ground soil temperature in summer might be enhanced by the increased summer precipitation in the eastern TP.

The maximum depth of frozen ground had a clear and significant effect on soil temperatures at all depths, with negative correlations between these variables. As seen in Table 6, the largest negative correlations were associated with the maximum depth of frozen ground for all stations. These results indicate that frozen ground has some inhibitory effect on increasing soil temperatures because of absorbing phase change energy. As described in Section 5, the strongest trends at the 0 and $80 \mathrm{~cm}$ soil layers occurred in winter for the Changdu station. These results also indicate that the warming trends in soil temperature are more affected by air temperature when depth of frozen ground is shallower. Moreover, the changes that occur during the freeze/thaw cycle could affect the increasing trends of soil temperature. From Section 5, smaller warming trends in October were evident at depths of 0-20 cm at all stations. Similarly, smaller warming trends were observed in March, February and January at the above-mentioned depths. Similar results regarding the buffering effect of the freezing and thawing process for seasonal changes in soil temperatures have been found in a simulation experiment conducted by Chen et al. (2014). As reported in Section 5, there were larger warming trends recorded in September at depths of $0-20 \mathrm{~cm}$ at all stations. One possible reason is that the date of the start of soil freezing is occurring later as a result of climate change (Gao et al. 2003). Slower cooling results in greater soil temperature warming trends observed in September. With the earth warming and the maximum depth of frozen ground gradually decreasing, the warming trends in soil temperature will continue due to the weakened inhibitory effect of frozen soil. This will contribute to a positive feedback loop which will continue to hasten soil and air warming.

\section{CONCLUSIONS}

Significant soil warming was detected in the TRSR of the TP between 1980 and 2014. Rates of increase were $0.706^{\circ} \mathrm{C}$ decade $^{-1}$ for surface soils $(0 \mathrm{~cm})$, $0.477^{\circ} \mathrm{C}$ decade $^{-1}$ for shallow layer soils $(0-20 \mathrm{~cm})$ and $0.417^{\circ} \mathrm{C}$ decade $^{-1}$ for deep layer soils (40$320 \mathrm{~cm}$ ). At most of the meteorological stations, surface and $5 \mathrm{~cm}$ depth layers of the soil were affected by warming during the winter, whereas soil temperature increases in the summer were more evident in the deeper layers $(10-320 \mathrm{~cm})$ than in the upper layers $(0-5 \mathrm{~cm})$.

Air temperatures also rose significantly in the TRSR during the 35 yr analysed, with an annual average increase of $0.458^{\circ} \mathrm{C}$ decade $^{-1}$. There was a clear effect of air temperature on soil temperatures, as seen from the significant and concurrently increasing trends in both air and soil temperatures, and from the strong correlation between these temperatures. This relationship was stronger in summer and winter than that in spring and autumn.

Precipitation amounts at most stations increased over the study period, but not obviously so. The relationship between precipitation and soil temperatures is very complicated, with precipitation feedback mechanisms occurring in spring and thermal insulating effect of snow occurring in winter. More precipitation on the ground also results in higher soil temperatures during the summer in the frozen soil. The freezing and thawing process also has some inhibitory effects on increasing soil temperatures. The warming trends of soil temperature will continue with the degradation of frozen soil in the TRSR.

Acknowledgements. This work was supported by the National Natural Science Foundation of China (No. 41375077 41130961, and 91537104). We are grateful to the China Meteorological Data Sharing Service System for supplying the data for the TRSR. Special thanks are given to the anonymous reviewers and the editor for very constructive comments. 


\section{LITERATURE CITED}

Alamusa, Niu C, Zong Q (2014) Temporal and spatial changes of freeze-thaw cycles in Ulan'aodu region of Horqin Sandy Land, northern China in a changing climate. Soil Sci Soc Am J 78:89-96

Bai Y, Scott TA, Min Q (2014) Climate change implications of soil temperature in the Mojave Desert, USA. Front Earth Sci 8:302-308

Chen B, Luo S, Lü S, Zhang Y, Ma D (2014) Effects of the soil freeze-thaw process on the regional climate of the Qinghai-Tibet Plateau. Clim Res 59:243-257

Cheng G (1998) Glaciology and geocryology of China in the past 40 years: progress and prospect. J Glaciol Geocryol 20:213-216 (in Chinese with English abstract)

Cheng G, Jin H (2013) Permafrost and groundwater on the Qinghai-Tibet Plateau and in northeast China. Hydrogeol J 21:5-23

CMA (China Meteorological Administration) (2003) Specifications for surface meteorological observation. China Meteorological Press, Beijing (in Chinese)

> Davidson EA, Janssens IA (2006) Temperature sensitivity of soil carbon decomposition and feedbacks to climate change. Nature 440:165-173

Du J, Li C, Liao J, Lhak P, Lu H (2007) Responses of climatic change on soil temperature at shallow layers in Lhasa from 1961 to 2005. Meteorol Monogr 33:61-67 (in Chinese with English abstract)

Gao R, Wei Z, Dong W (2003) Interannual variation of the beginning date and the ending date of soil freezing in the Tibetan Plateau. J Glaciol Geocryol 25:49-54 (in Chinese with English abstract)

> García-Suárez AM, Butler CJ (2006) Soil temperatures at Armagh Observatory, Northern Ireland, from 1904 to 2002. Int J Climatol 26:1075-1089

Gilbert RO (1987) Statistical methods for environmental pollution monitoring. Wiley, New York, NY

$>$ Gocic M, Trajkovic S (2013) Analysis of changes in meteorological variables using Mann-Kendall and Sen's slope estimator statistical tests in Serbia. Global Planet Change 100:172-182

Guo D, Wang H (2012) The significant climate warming in the northern Tibetan Plateau and its possible causes. Int J Climatol 32:1775-1781

Guo D, Wang H (2013) Simulation of permafrost and seasonally frozen ground conditions on the Tibetan Plateau, 1981-2010. J Geophys Res 118:5216-5230

Hamed KH, Rao AR (1998) A modified Mann-Kendall trend test for autocorrelated data. J Hydrol 204:182-196

Hollander M, Wolfe DA, Chicken E (2013) Nonparametric statistical methods, 3rd edn. John Wiley \& Sons, New York, NY

$>$ Hu Q, Feng S (2003) A daily soil temperature dataset and soil temperature climatology of the contiguous United States. J Appl Meteorol 42:1139-1156

$\mathrm{Hu} \mathrm{H}$, Liang L (2013) Temporal and spatial variations of rainfall at the east of Qinghai-Tibet Plateau in last 50 years. Plateau Mountain Meteorol Res 33:1-7 (in Chinese with English abstract)

> Jin H, He R, Cheng G, Wu Q, Wang S, Lü L, Chang X (2009) Changes in frozen ground in the source area of the Yellow River on the Qinghai-Tibet Plateau, China, and their eco-environmental impacts. Environ Res Lett 4:045206, doi:10.1088/1748-9326/4/4/045206

Kendall MG (1955) Rank correlation methods. Charles Grif- fin \& $\mathrm{Co}$, London

> Kurylyk BL, MacQuarrie KTB, McKenzie JM (2014) Climate change impacts on groundwater and soil temperatures in cold and temperate regions: implications, mathematical theory, and emerging simulation tools. Earth Sci Rev 138: 313-334

> Lawrence DM, Slater AG, Swenson SC (2012) Simulation of present-day and future permafrost and seasonally frozen ground conditions in CCSM4. J Clim 25:2207-2225

> Liang L, Li L, Liu C, Cuo L (2013) Climate change in the Tibetan Plateau Three Rivers Source Region: 1960-2009. Int J Climatol 33:2900-2916

Liu X, Chen B (2000) Climatic warming in the Tibetan Plateau during recent decades. Int $\mathrm{J}$ Climatol 20: 1729-1742

Mann HB (1945) Nonparametric tests against trend. Econometrica 13:245-259

Nelson FE (2003) (Un)frozen in time. Science 299:1673-1675

Qian B, Gregorich EG, Gameda S, Hopkins DW, Wang XL (2011) Observed soil temperature trends associated with climate change in Canada. J Geophys Res 116:D02106, doi:10.1029/2010JD015012

Ran Y, Li X, Cheng G, Zhang T, Wu Q, Jin H, Jin R (2012) Distribution of permafrost in China: an overview of existing permafrost maps. Permafrost Periglac Process 23: 322-333

> Sen PK (1968) Estimates of the regression coefficient based on Kendall's Tau. J Am Stat Assoc 63:1379-1389

Shen M, Piao S, Jeong SJ, Zhou L and others (2015) Evaporative cooling over the Tibetan Plateau induced by vegetation growth. Proc Natl Acad Sci USA 112: 9299-9304

Wei F (2007) Modern climatic statistical diagnosis and prediction technology; 2nd edn. China Meteorological Press, Beijing (in Chinese)

Wu Q, Zhang T, Liu Y (2012) Thermal state of the active layer and permafrost along the Qinghai-Xizang (Tibet) railway from 2006 to 2010. The Cryosphere 6:607-612

Xu W, Gu S, Su W, Jiang S, Xiao R, Xiao J, Zhang J (2012) Spatial pattern and its variations of aridity/humidity during 1971-2010 in Three River Source Region on the Qinghai Tibet Plateau. Arid Land Geogr 35:46-55 (in Chinese with English abstract)

Xue X, Guo J, Han B, Sun Q, Liu L (2009) The effect of climate warming and permafrost thaw on desertification in the Qinghai-Tibetan Plateau. Geomorphology 108: 182-190

Yeşilırmak E (2014) Soil temperature trends in Büyük Menderes Basin, Turkey. Meteorol Appl 21:859-866

Yi X, Yin Y, Li G, Peng J (2011) Temperature variation in recent 50 years in the Three-River headwaters region of Qinghai Province. Acta Geogr Sin 66:1451-1465 (in Chinese with English abstract)

You Q, Kang S, Li C, Yan Y, Yan S (2008) Change in extreme temperature over San Jiang Yuan region in the period from 1961 to 2005. Resour Environ Yangtze Basin 17: 232-236 (in Chinese with English abstract)

> You Q, Min J, Fraedrich K, Zhang W, Kang S, Zhang L, Meng X (2014) Projected trends in mean, maximum, and minimum surface temperature in China from simulations. Global Planet Change 112:53-63

You Q, Min J, Lin H, Pepin N, Sillanpää M, Kang S (2015) Observed climatology and trend in relative humidity in the central and eastern Tibetan Plateau. J Geophys Res 120:3610-3621 
Zhang T, Barry RG, Gilichinsky D, Bykhovets SS, Sorokovikov VA, Ye J (2001) An amplified signal of climatic change in soil temperatures during the last century at Irkutsk, Russia. Clim Change 49:41-76

Zhang W, Li S, Pang Q (2009) Changes of precipitation spatial-temporal over the Qinghai-Tibet Plateau during last 40 years. Ad Water Sci 20:168-176 (in Chinese with

Editorial responsibility: Gouyu Ren,

Beijing, China
English Abstract)

Zheng J, Yin Y, Li B (2010) A new scheme for climate regionalization in China. Acta Geogr Sin 65:3-12 (in Chinese with English abstract)

Zhu X, Wang W, Fraedrich K (2013) Future climate in the Tibetan Plateau from a statistical regional climate model. J Clim 26:10125-10138

Submitted: June 23, 2015; Accepted: December 28, 2015 Proofs received from author(s): February 26, 2016 